\title{
ANALIZA OSIGURANJA MOTORNIH VOZILA U REPUBLICI SRBIJI U PERIODU OD 2016. DO 2020. GODINE
}

\section{THE ANALYISIS OF MOTOR VEHICLE INSURANCE IN THE REPUBLIC OF SERBIA IN THE PERIOD FROM 2016. TO 2020.}

\author{
Mladen Čulić, Fakultet tehničkih nauka, Novi Sad
}

\section{Oblast - INŽENJERSKI MENADŽMENT}

Kratak sadržaj - U radu je izvršena analiza karakteristika osiguranja motornih vozila u Republici Srbiji za period od 2016. do 2020 godine na osnovu teorijsih pretpostavki datih u uvodu rada i podataka sa tržišta Srbije. Na osnovu analize se može zaključiti da je trenutno stanje solidno kada se uporedi sa stanjem $u$ regionu, a kada se uočeno stanje uporedi sa situacijom $u$ razvijenim zemljama, posebno zemljama EU, može se uočiti da je potrebno još dosta raditi na razvoju sektora osiguranja uopšte, pa samim tim i na osiguranju motornih vozila kao sastavnim delom kompletne ponude osiguranja.

Ključne reči: Osiguranje, Rizik, Osiguranje motornih vozila

Abstract - The paper analyzes the characteristics of motor vehicle insurance in the Republic of Serbia for the period from 2016 to 2020 on the basis of theoretical assumptions given in the introduction to the work and data from the Serbian market. Based on the analysis, it can be concluded that the current situation is solid when compared to the situation in the region, and when the situation is compared with the situation in developed countries, especially EU countries, it can be seen that much work is needed to develop the insurance sector in general and thus on motor vehicle insurance as an integral part of the complete insurance offer.

Keywords: Insurance, Risk, Motor vehicle insurance

\section{UVOD}

Osiguranje motornih vozila je jedna od najrazvijenijih vrsta osiguranja koja, u odnosu na druge vrste, ima značajan broj redovnih korisnika. Razlog za to je što je broj vozača motornih vozila iz godine $u$ godinu $u$ Republici Srbiji rastao, a osiguranje samih vozila predstavlja jednu od obaveza vozača pre nego što se svojim vozilom zapute $\mathrm{u}$ bilo kom pravcu. Kako je osiguranje motornih vozila nešto sa čim se danas veoma često susrećemo i kako je isto nešto o čemu bi svaki građanin trebao da bude informisan, ovaj rad predstavlja kratak pregled koji čitaoca treba da uvede u osiguranje i upozna ga sa najvažnijim informacijama koje bi trebao da zna i koje mogu da mu budi interesantne i korisne.

\section{NAPOMENA:}

Ovaj rad je proistekao iz master rada čiji mentor je bio prof. dr Đorđe Ćosić.

\section{OSNOVNI POJMOVI U OSIGURANJU}

Osiguranje predstavlja institut društvene reprodukcije koje deluje kao osnovni korektivni alat u odnosu na poremećaje koji koji nastaju zbog dejstava različitih rušilačkih sila izazvanih prirodnim ili ljudskim faktorom. Inače, sama reč osiguranje predstavlja pružanje sigurnosti, obezbeđenje i poverenje. Na osnovu ovih pojmova je $\mathrm{i}$ izgrađen princip i tehnika poslovanja osiguranja i organizacija koje se bave osiguranjem. Suština osiguranja se ogleda u udruživanju onih subjekata koji su izloženi istim opasnostima sa ciljem zajedničkog snošenja štete ukoliko ona $\mathrm{u}$ nekom momenuti i nastane. Rezultat ovakvog načina reagovanja na opasnost je izjednačavanje rizika na prihvatljivom nivou, pa pojedinci lakše mogu da podnesu određene posledice na ovaj način u odnosnu na slučaj kada bi to morali sami.

\subsection{Pojam i definicija osiguranja}

Osiguranje predstavlja multidisciplinarnu naučnu oblast koja se može posmatrati sa različitih aspekata, od kojih se najčešće izdvajaju sledeća tri:

$$
\begin{array}{ll}
>\quad \text { Ekonomski aspekt, } \\
>\quad \text { Pravni aspekt, } \\
\text { Tehnički aspekt. }
\end{array}
$$

Ekonomski apsekt se iskazuje kroz cilj da je potrebno zaštititi čoveka ili njegovu imovinu, a uočava se kroz ekonomske odnose koji se uspostavljaju između različitih (fizičkih ili pravnih) licau okviru poslova osiguranja. Pravni aspket osiguranja se ogleda u proučavanju prava $\mathrm{i}$ obaveza ugovornih strana koje zaključuju ugovor o osiguranju. Na kraju, tehnički apsekt predstavlja upotrebu savremenih metoda (najčešće su to matematičkostatističke metode) kako bi se obavili potrebni poslovi u okviru pružanja usluge osiguranja.

“Osiguranje je specifična privredna delatnost koju obavljaju posebni privredni subjekti, društva za osiguranje, radi pružanja materijalne zaštite fizičkim $i$ pravnim licima od posledica osiguranih rizika na osnovu primene posebnih pravnih pravila $i$ pravila tehnike osiguranja zasnovane na statistici i matematici." [1]

Ovakvo osiguranje ima tri osnovne/glavne funkcije koje se danas sprovode u osiguravajućim društvima:

$$
\begin{aligned}
& >\text { Zaštita imovine i lica kao primarne } \\
& \text { funkcije, } \\
& >\quad \text { Akumuliranje finansijskih uplata } \\
& \text { (finansijska funkcija), } \\
& >\quad \text { Socijalna funkcija. [2] }
\end{aligned}
$$

Što je razvijenija delatnost osiguranja, to je razvijenija i svest svih pravnih i fizičkih lica o potrebi za osiguranjem. 
Kao posledica navedenog nastaje i razvoj svake od prethodno navedenih pojedinačnih funkcija osiguranja.

\subsection{Istorijat osiguranja}

Postoje brojne pretpostavke po pitanju toga $\mathrm{u}$ kom momentu i na koji tačno način je nastalo osiguranje. Brojni naučnici koji se bave ovom oblašću su pokušali da daju odgovor na ovo pitanje istraživajući najrazličitije izvore iz arhiva širom sveta. Ono što je sigurno jeste da osiguranje kakvo danas poznajemo nije nastalo odjednom, već se do toga došlo postepenim razvojem i nadogradnjom kroz vreme.

Prvi zvanični oblik osiguranja se javio kada je došlo do većeg razvoja saobraćaja i trgovine robom. Iako se u dato vreme to stanje smatralo naprednim, u odnosnu na stanje danas je bilo dosta primitivno. Taj primitivan način rukovanja predmetima transporta i trgovine je jedan od rizika koji je uočen i koji je naveo ljude da razmišljaju o načinima na koje mogu da zaštite svoju robu. U ovom momentu su pored standardnih preventinih mera čuvanja prvi put upotrebljene i mere koje se mogu povezati sa današnjim osiguranjem.

Koreni i ideje o osiguranju su izuzetno značajni, ali na razvoj današnjeg osiguranja najveći uticaj ima otkriće Amerike. U ovom momentu količine robe koje se transportuju postaju sve veće, a razdaljine koje se prelaze pri tom transportu takođe rastu. Vodeću ulogu u ovom poduhvatu imala je i Engleska u kojoj je otvorena pravo organizacija za obavljanje poslova osiguranja, odnosno osiguravajuće društvo 1547. godine.

Prvi tragovi osiguranja kod nas su pronađeni $u$ Dušanovom Zakoniku koji datira iz 1349. godine. Ovaj oblik osiguranja se može smatrati primitivnim oblikom koji je pomagao lokalnom stanovništvu da olakša podnošenje gubitaka na principu koji je sličan osiguranju. Svakako, moderno osiguranje se i kod nas javlja u drugoj polovinin XIX veka pod uticajme zapada koji je prvi i pokrenuo ovaj trend. Prvo osiguranje u Republici Srbiji je ostvareno i ubeleženo 1839. godine. Prvo su osnovane filijale inostranih osiguravajućih društava, a tek su kasnije počele da se otvaraju i poneka u domaćem vlasništvu.

\subsection{Elementi osiguranja}

Procesi osiguranja obuhvataju određeni broj različitih elemenata koji imaju različite uloge. Svaki od ovih elemenata na određeni način doprinosi da se proces osiguranja uspešno obavi, odnosno da predstavlja zaokružen i funkcionalan proces. Elementi su:

$\begin{array}{ll}> & \text { Osigurani slučaj, } \\ > & \text { Suma osiguranja, } \\ > & \text { Polisa osiguranja, } \\ > & \text { Premija osiguranja, } \\ & \text { Bonus i malus. }\end{array}$

Svi navedeni elementi su pre svega razvijeni kako bi se proces osiguranja obavio na što jedinostavniji način. $U$ kom smislu jednostavniji? Tako što je moguće ispratiti kretanje i uticaj svakog od njih što direktno ukazuje učesnicima u procesu osiguranja na koji način treba da se ponašaju, gde nastaju eventualni problemi i gde postoji prostor za unapređenja. Način na koji je obavljanje delatnosti osiguranja danas uređeno uz pomoć navedenih elemenata je dove do toga da se profitabilnost iste podigne na značajno viši nivo i da se stekne viši nivo povrenja ljudi koji onda i postaju klijenti osiguravajućih društava učestalije i ostaju u njima znatno duži vremenski period.

\subsection{Subjekti u osiguranju}

Subjekti u osiguranju se dele na osnovne koji se uvek javljaju u ovom procesu i ostale koji mogu da se javljaju ukoliko se za tim ukaže potreba ali i ne moraju. Osnovna dva subjekta u procesu osiguranja su:

$\begin{array}{ll}> & \text { Osiguranik i } \\ > & \text { Osiguravač [3] }\end{array}$

Osiguranik se može javiti kao pravno lice ili kao fizičko lice. Lice koje zaključi ugovor o osiguranju za svoje ime i svoj račun je osiguranik. Osiguranik je lice čija je imovina ili život osiguran kod osiguravajućeg društva. Osiguravač je (obavezno) pravno lice koje na sebe preuzima rizik oštećenja ili uništenja određene stvari, kao i rizik prevremene smrti kod osiguranja lica i druge rizike od pravnog ili fizičkog lica koje je izloženo datim rizicima. Osiguravač je prvano lice koje se ugovorom o osiguranju obavezuje da će nadoknaditi štetu, odnosno isplatiti ugovorenu vrednost osiguranja kada nastane osigurani slučaj. Osiguravači se razlikuju prema načinu osnivanja, a takođe se mogu podeliti i prema vrsti osiguranja koje prodaju, zakonskom obliku njihovog vlasništva ili sistemu propagande kojim se služe.

Ostali učesnici u procesima osiguranja mogu da budu sledeći:

$$
\begin{array}{ll}
> & \text { Korisnik osiguranja, } \\
> & \text { Ugovarač osiguranja, } \\
> & \text { Posrednik u osiguranju, } \\
& \text { Zatupnik u osiguranju [4]. }
\end{array}
$$

\section{PODELA OSIGURANJA}

U momentu kada osiguravajuće kuće nove rizike nisu mogle da vode $\mathrm{u}$ okviru poznatih (postojećih) grupa osiguranja razijane su nove grupe što je dovelo do širenja mogućnosti za posmatranje i analizu osiguranja i iz ugla osiguravača i iz ugla osiguranika [5].

Najznačajnija podela koja polazi od specifičnih obaveza osiguravača i osiguranika prihvaćena je u zakonu koji reguliše ugovor o osiguranju, a to je podela na osiguranje imovine i osiguranje lica. Ova podela se smatra podelom sa stanovišta prava osiguranja. Kod osiguranja imovine osiguravajuće društvo ima obavezu da, u momentu kada nastane osigurani slučaj, obešteti osiguranika ili treće lice koje na to ima pravo po ugovoru osiguranja u iznosu koji je direktno određen uslovima iz ugovora i obimom nastale štete koja treba da se pokrije. Kod osiguranja lica osiguravajuća kuća ima obavezu da isplati jedan paušalni iznos čija visina je utvrđena u ugovoru osiguranja.

Druga začajna podela koja je karakteristična po tome što je "novijeg datuma", odnosno kreirana u bliskoj prošlosti, je utvrđena $u$ komunitarnom pravu. To je podela osiguranja koja se smatra tehničkom, jer se zasniva na načinu upravljanja zajednicom rizika i usvojena je takođe u zakonima evropskih zemalja koji regulišu delatnost osiguranja. Ona ima osnovni značaj za delatnost osiguranja jer svako društvo koje se bavi poslovima osiguranja može da dobije dozvolu nadležnog organa koj sprovodi kontrolu osiguranja za obavljanje jedne od dveju ovih grupa osiguranja, a to su životno i neživotno osiguranje. 


\section{POJAM RIZIKA I NJEGOVA VEZA SA OSIGURANJEM}

Rizik predstavlja verovatnoću da će nastati/nastupiti neki negativni efekati na poslovni i fnansijski rezultat, a možda i na položaj jednog osiguravajućeg društva. Sa druge strane, upravljanje rizikom možemo da defnišemo kao proces identifkacije, merenja, procene i kontrole rizika. Rizik takođe može da se posmatra i kao mogućnost da se dogodi nešto što će ostaviti negativne posledice na ciljevima koji su postavljeni. Rizik možemo da procenjujemo sa obzirom na posledice koje nastupe i sa obzirom na verovatnoću njegovog ostvarenja. Upravljanje rizikom uopšteno može da podrazumeva čitav sklop tehnika i metoda za smanjenje učestalosti i veličine gubitka koji nastaju kao posledica tih rizika. Dominiraju četiri metoda odgovora na rizike, a to su:

$$
\begin{array}{ll}
> & \text { Izbegavanje, } \\
> & \text { Prihvatanje, } \\
> & \text { Umanjenje i } \\
& \text { Deljenje rizika. }
\end{array}
$$

Definicija upravljanja rizikom je sledeća: “Upravljanje rizicima u osiguravajućoj kući možemo da defnišemo kao proces koji deluje na potencijalne događaje koji utiču na ciljeve, zadržava rizike unutar granica tolerancije $i$ obezbeđuje racionalno ostvarenje postavljenih ciljeva" [6].

U poslednjih nekoliko decenija se stvara nova poslovna filozofija osiguravajućih društava kod koje kapital predstavlja drugu liniju odbrane od insolventnosti osiguravača, dok prvu odbrambenu liniju čini odgovarajuće upravljanje rizicima. Drugim rečima, rizicima se iz godine u godinu pridaje sve veći značaj, a njihova analiza postaje sve ozbiljniji proces. Osiguravajuća društva svoje lične interese mogu zaštititi tako što će svoje jake želje za postizanjem određenih rezultata, po preuzimanju rizika, prilagoditi kapitalu koji su stvarno spremni da izlože riziku.

\section{OSIGURANJE MOTORNIH VOZILA}

Pre svega, važno je napomenuti da postoji više vrsta osiguranja motornih vozila. U ovom radu fokus će biti stavljen na osnovnu podelu kod koje razlikujemo dve grupe, odnosno dve različite vrste osiguranja, a to su:

$>$ Dobrovoljno, ili kasko osiguranje motornih vozila $\mathrm{i}$

Obavezno osiguranje motornih vozila.

Navedene dve grupe osiguranja se razlikuju na više različitih osnova. Najvažnije razlike se uočavaju kod uslova u vezi plaćanja premije osiguranja, osiguranih rizika koje svaki od ugovora može da pokrije i kod načina na koje se vrši naknada štete kada osigurani rizik nastupi. Sve navedene karakteristike su predstavljene u narednim tačkama ovog poglavlja.

Kasko osiguranje motornih vozila je vrsta neživotnog osiguranja koje se sklapa na dobrovoljnoj osnovi između lica koje ugovara osiguranje i osiguravajućeg društva. Ugovorom o osiguranju motornih vozila osiguravač se obavezuje danadoknadi materijalnu štetu na osiguranom vozilu, te i drugim osiguranim predmetima u vozilu i/ili na vozilu ako ista nastane kao reultat nasupanja osiguranog rizika [7].

Obavezno osiguranje je nastalo kao rezultat uočavanja određenih obrazaca i ponovljenih dešavanja nesrećnih slučajeva u toku obavljanja prevoza. Na osnovu toga možemo reći da obavezno osiguranje ima sledeće karakteristike i uslovljeno je sledećim pojavama:

Veliki rizici i štete kao i spajanje više različitih osiguranja u jednom događaju,

$>\quad$ Pojava čitavog niz lica koja u jednoj operaciji prevoza mogu da se pojave kao nosioci interesa za osiguranje,

D Zaključivanje ugovora je po pravilu neformalno, odnosno nije u pisanoj formi itd.

Obavezna osiguranja su okrenuta ka dva osnovna pravca kada se radi o naknadi štete, pa je na osnovu toga moguće podeliti ovu grupu osiguranja na:

$>\quad$ Osiguranja lica i robe koja se nalaze u prevoznom sredstvu i postanu deo nesrećnog slučaja kada nastupi osigurani rizik i

$>$ Osiguranje korisnika vozila od odgovornosti za štetu koja je naneta trećem licu po nastupanju osiguranog rizika.

I jedna i druga navedena grupa osiguranja se zaključuje putem ugovora po istom princpu, ali se u ugovoru samo dati predmet osiguranja razlikuje.

\section{ANALIZA OSIGURANJA MOTORNIH VOZILA U REPUBLICI SRBIJI U PERIODU OD 2016. DO 2020. GODINE}

Tržište osiguranja nije izuzetak kada govorimo o promenama u skladu sa trendovima, tehnologiji ili znanju. I na ovom tržištu se mogu uočiti promene koje su nastale kao rezultat brojnih uticaja koji dolaze iz najrazličitijih sfera nauke i života. U ovom poslednjem poglavlju rada bavimo se time kako su navedeni uticaj i promene delovali na tržište osiguranja motornih vozila u Republici Srbiji u poslednjih pet godina.

\subsection{Učesnici na tržištu osiguranja u Republici Srbiji}

Prema zvaničnim informacijama koje se nalaze u izveštajima Narodne banke Srbije, na teritoriji naše zemlje trenutno posluje oko 21 društavo za osiguranja i/ili za reosiguranje, a pored njih postoji i oko 80 društava koja se bave posredovanjem u osiguranju. Mimo navedenih učesnika javljaju se i različita fizička lica ili preduzetnici u ulozi zastupnika u osiguranju, ali i banke i ovlašćeni aktuari. Nas u ovom radu zanimaju isključivo osiguravajuća društva pa će u nastavku biti predstavljene informacije vezane za njih. Ovih društava ima ukupno 17 , dok se preostala 4 društva od prethodno navedenih 21 bave isključivo poslovima reosiguranja. Od 17 osiguravajućih društava 4 se bavi isključvio životnim osiguranjima, 6 isključivo neživotnim osiguranjima, a preostalih 7 društava se bavi poslovima i životnog i neživotnog osiguranja.

Svake godine Narodna banka Srbije, ali i druge institucije koje se bave poslovanjem osiguravajućih društava, vrše analizu poslovanja $\mathrm{i}$ prave rang top 5 najboljih osiguravajućih društava prema različitim kriterijumima. Rang za 2020. godinu na osnovu ukupne premije je sledeći:
1. Dunav osiguranje,
2. Generali osiguranje,
3. Wiener osiguranje,
4. DDOR osiguranje,
5. Triglav osiguranje. 
Kako je osiguranje na koje se fokusiramo u ovom poslednjem poglavlju osiguranje motornih vozila, najvažnija analiza od onih koje su prethodno urađene je ona sa stanovišta premije neživotnih osiguranja, jer osiguranje motornih vozila pripada grupi neživotnih osiguranja. Dakle, u Republici Srbiji, osiguravajuće kuće koje imaju najveći broj klijenata na polju neživotnih osiguranja su:

$\begin{array}{ll}> & \text { Dunav osiguranje, } \\ > & \text { Generali, } \\ > & \text { DDOR, } \\ > & \text { Wiener } \mathrm{i} \\ & \text { Triglav. }\end{array}$

Ono što je važno napomenuti je da ovih top 5 osiguravajućih društava, kada im se saberu učešća po osnovu premije neživotnih osiguranja, odnose 83,6\% učešća na ovom tržištu osiguranja.

\subsection{Karakteristike osiguranja motornih vozila $u$ Republici Srbiji}

Sektor osiguranja je kod nas danas mahom privatizovan. Domaćim sektorom osiguranja dominiraju kompanije u većinskom stranom vlasništvu. Gotovo celokupna premija životnih osiguranja i skoro dve trećine neživotnih prikupi se od strane društava sa većinskim stranim kapitalom. [8] Očekivanja su da će srpsko tržište osiguranja nastaviti da se razvija brže od susednih zemalja. Društva za osiguranje u Republici Srbiji se usmeravaju i promovišu online prodaju, banko-osiguranje ili kreiraju specifične proizvode za mala i srednja preduzeća, odnosno povećavaju prisutnost u određenim vrstama osiguranja. Na taj način osiguravajuća društva pokušavaju da podstaknu potencijalne klijente da postanu stalni klijenti i zajedno sa njima poboljšaju statistiku i generalno stanje na tržištu osiguranja u odnosu na države regiona i Evropske Unije. Sve navedeno ima uticaj i na osiguranje motornih vozila, kako ono koje je obavezno tako i na ono koje ima dobrovoljni karakter. Osiguranje motornih vozila je jedno od osiguranja koje se po broju korisnika i visini ukupne godišnje premije nalazi u samom vrhu.

\subsection{Premija osiguranja motornih vozila i analiza njenog kretanja u periodu od 2016. do 2020. godine}

Predstavljeno je kretanje premije osiguranja motronih vozila korz prva tri tromesečja 2020. godine kako bi se lako uočila tendencija rasta ukupne premije osiguranja, bilo da se radi o obaveznim ili dobrovoljnim.

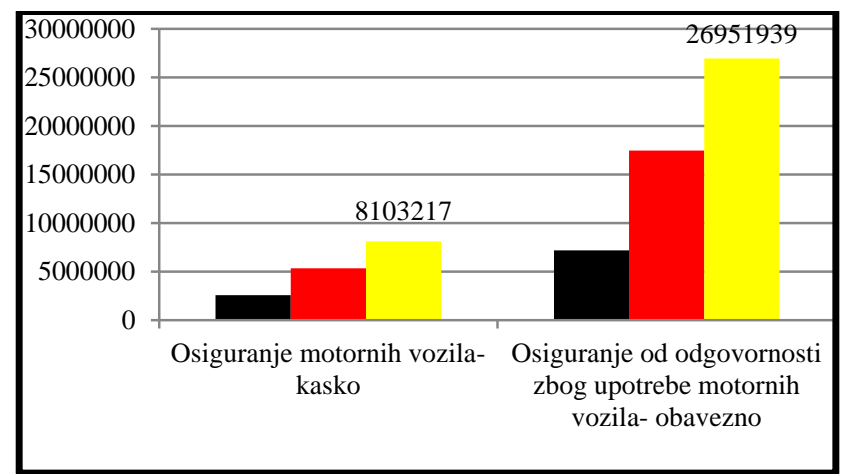

Grafik 1. Kretanje ukupne premije osiguranja motornih vozila u prva tri tromesečja 2020 . godine $u$ hiljadama dinara [9]
Ono što je važno napomenuti je primećen trend rasta broja motornih vozila u vlasništvu građana Republike Srbije, što takođe ima direktan uticaj na navedeno kretanje premije osguranja motornih vozila u poslednjih pet godina.

Na kraju, možemo da kažemo da je opšti utisak o osiguranju motornih vozila na tržištu osiguranja Republike Srbije pozitivan. Broj korisnika osiguranja motornih vozila raste, pa samim tim i ukupna premija osiguranja, što nas navodi na to da će u bliskoj budućnosti verovatno biti razvijen potencijal da se dostignu postavljeni kriterijumi i rezultati zemalja Evropske Unije na čiji standard se i ugledamo kao zemlja u razvoju.

\section{ZAKLJUČAK}

Što se tiče osiguranja motornih vozila na teritoriji Republike Srbije, možemo da izvučemo kratak zaključak da je njegovo trenutno stanje solidno kada se uporedi sa stanjem u regionu. Kada se uočeno stanje uporedi sa situacijom u razvijenim zemljama, posebno zemljama EU, može se uočiti da je potrebno još dosta raditi na razvoju sektora osiguranja uopšte, pa samim tim i na osiguranju motornih vozila kao sastavnim delom kompletne ponude osiguranja.

Kako bi se dostigli rezultati koji su uobičajeni za razvijene zemlje potrebno je raditi prvenstveno na dodatnom podizanju svesti stanovništva o potrebama za osiguranjima., ali pored toga i na organizaciji samog sektora osiguranja, tehnologijama koje se koriste u poslovanju i obučavanju kadra koji je zaposlen u ovom sektoru.

\section{LITERATURA}

[1] Jeremić, L. Barjaktarović, L. Pak, J. (2012). Osnovi osiguranja. Beograd.

[2] Vasić, B. Miloradić, J. (2018). Privredni značaj osiguranja kroz proces upravljanja rizicima. Novi Sad.

[3] Avdalović, V. (2007). Osiguranje. Beograd.

[4] Balaban, M. (2011). Pojam, elementi $i$ vrste osiguranja. Beograd.

[5] Pak, J. (2011). Pravo osiguranja. Beograd.

[6] Sokić, M. (2016). Unapređenje sistema upravljanja rizicima $u$ osguravajućoj kompaniji. Beograd.

[7] Nedić, N. (2015). Aktuelno stanje i problemi osiguranja motornih vozila u Srbiji. Beograd.

[8] Jevremović, S. (2020). Komparativna analiza performansi osiguranja u Evropskoj Uniji $i$ zemljama zapadnog Balkana. Beograd.

[9] Narodna banka Srbije. (2020). Ukupna premija $i$ raspored premije po vrstama osiguranja društava za osiguranje. Beograd.

\section{Kratka biografija:}

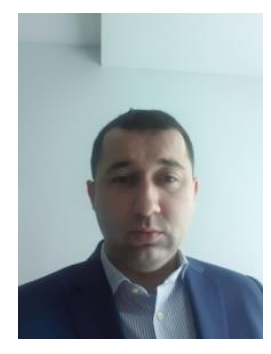

Mladen Čulić rođen je u Mrkonjić Fradu 1987.. godine. Master rad na fakultetu tehničkih nauka iz oblasti Industrijsko inženjerstvo i menadžment odbranio je 2021. godine.

mladen.culic@trznica-bl.com 